\title{
The Fourth Plenum of the CPC Makes an Important Decision on Law Reform in China
}

\author{
KJELD ERIK BRØDSGAARD AND NIS GRÜNBERG
}

\begin{abstract}
During the Fourth Plenary Session of the 13th Communist Party of China (CPC) Congress, a new and important reform document was adopted. Announcing reforms mainly in the juridical sector, the 'Decision of the CPC Central Committee Concerning Some Major Questions in Comprehensively Moving Governing the Country According to the Law Forward' is part of the overall reform package kicked off at the Third Plenum last year. This article points out the document's main objectives, and provides a preliminary analysis of the announced reforms. Three main themes are identified. First, the document is part of the overall goal of developing a special Chinese system of 'socialism with Chinese characteristics'. Second, not only institutions but also the minds and work styles of officials are to be reformed. Third, the document strongly affirms the CPC's role as the legal guardian of the reform process, as well as juridical matters.
\end{abstract}

From October 20-23, 2014, the Central Committee of the Communist Party of China (CPC) met for its fourth plenary session and passed a major document titled 'Decision of the CPC Central Committee Concerning Some Major Questions in Comprehensively Moving Governing the Country According to the Law Forward' (hereafter: Decision) (Xinhua 2014a), which was drafted by a group headed by President Xi Jinping. Xi had also served as chair of the group that drafted the landmark 'Decision of the CPC Central Committee on Some Important Questions Concerning Comprehensively Deepening Reform' adopted by the Third Plenary Session in November 2013 (Xinhua 2013; Brødsgaard and Grünberg 2014). Whereas the earlier decision from November 2013 focused on economic, political and social reform policies, the more recent one sets out the direction for a number of initiatives and reforms in legal matters.

It is telling that $\mathrm{Xi}$ also was head of the drafting group of the new Central Committee document. He has now been in power for two years, and during this relatively short period of time he has managed to consolidate his power considerably. He is not only General Secretary of the CPC, 
President of the PRC and head of the Central Military Commission, he is also head of a number of small leading groups as well as new agencies such as the National Security Council and the National Reform Group. In terms of policy making he is exercising increasing influence by heading these important Party groups charged with the formulation of strategic policy proposals and directions. This article gives a preliminary analysis of the recent Decision adopted at the Fourth Plenum, identifying three main objectives of the document. First, the Decision ties into the overall goal of building a specifically Chinese system of 'socialism with Chinese characteristics', by pushing relevant reforms of institutions and norms within the juridical system. These reforms should not be seen isolated, but as parts of a quite comprehensive attempt at reforming the Partystate as such. Second, the document sets out not only to reform formal institutions, but also the minds of both officials and the public. Numerous initiatives aim at promoting a 'rule of law culture', rooted in virtue, morality and responsibility. The third objective is a strong confirmation of the role of the CPC as the legal guardian of the constitution. This includes the recentralization of authority, especially at the province level, and the affirmation of the principle of top-down supervision.

Usually, the meetings of the central committee in between Party congresses follow a certain pattern. The first plenary session held immediately after the conclusion of a national Party congress elects the Politburo, its standing committee as well as the new general secretary. The second plenary session discusses and nominates new members of the country's next government. The third plenary session decides on the direction and principles of economic development during the first tenure of the new leadership. The fifth plenary session usually discusses the five-year plans, which subsequently are passed by the National People's Congress during its spring session. The sixth plenary session is often devoted to the cultural systems and cultural values covered by concepts such as harmonious society. The seventh plenary session is normally held one week before the national Party congress and lays the groundwork for the event, including the new leadership line-up.

The fourth plenary session usually focuses on Party building. However, this year, law and legal work took centre stage, extending the reform work initiated in 2013 into these issue areas. The current anti-corruption campaign has also made new directions in this area an urgent matter.

Revolving around the establishment of rule of law in China, or more precisely, a 'socialist rule of law with Chinese characteristics', the Decision is an important continuation and extension of the $\mathrm{Xi}$ ad- 
ministration's general reform programme into the juridical workings of the Party-state. While not as comprehensive and ambitious as the decisions issued after the third plenum last year, this recent document is important in showing how the CPC intends to use the juridical system in the general push to revitalize and strengthen the CPC's governance of the Party-state. The increased official use of the term yifa zhiguo (which can be translated as 'ruling the country according to law' or simplified, 'rule by law') over the last weeks, has puzzled many observers as to what exactly is meant by it, and how it compares to the Western notion of 'rule of law' (e.g. Huang 2014; Minzer 2014). The Fourth Plenum has given a number of indications about the precise meaning and consequences for the institutional structure. While some important and concrete reforms have been announced in the juridical system, large parts of the document serve the ongoing formulation of a consistent institutional logic throughout the system in both theory and practice. The core objective supported by the Decision is stated as the 'construction of a socialist rule of law system with Chinese characteristics, and the construction of a socialist rule of law country'. It is not about introducing a Western-style rule of law. China, in this as in so many other areas, will follow its own way.

\section{Socialist Rule of Law with Chinese Characteristics}

The precise meaning of the Chinese term yifa zhiguo has been discussed widely in the media, especially regarding the role of the CPC in the juridical system. Already in 2013, at the 30th anniversary of the implementation of the Chinese constitution on 4 December, Xi Jinping gave a speech on the 'rule in accord with the constitution' (yixian zhiguo). In retrospect, this seemed to be an early sign of Xi's intended reforms in the Party-state's juridical institutions. The Decision has now outlined in more detail how China's 'rule of law' is defined, and links the outlined reforms in the juridical system to the general reform programme announced at the third plenum last year. Moreover, it adds more detail to the theoretical conception of the Party-state as 'socialism with Chinese characteristics', clarifying - or more precisely confirming - the relationships between the CPC, the constitution and the juridical system.

This means that the Party will define the law and the Chinese constitutional order. It also means that the Party will continue to have its own institutions, rules and practices, which at times will take priority over state laws and regulations (Clarke 2014). Institutions such as po- 
litical legal committees, Party cells in courts, and Party control over the nomenklatura will persist. Practices such as detaining Party members for long periods of investigation (shuanggui) as well as Party review of major National People's Congress (NPC) legislation will also continue (Article 2, Section 2).

According to the Decision, the leadership of the CPC is a necessary precondition for rule according to the law and the constitution, since '...Party leadership and socialist rule of law are identical, socialist rule of law must persist in Party leadership, and Party leadership must rely on socialist rule of law' (Article 1). The '...implementation of leadership of the CPC in all processes and aspects of ruling the country according to law' is thus an effort to establish a 'socialist rule of law system' (Article 1). The term 'socialist rule of law with Chinese characteristics' must also be seen as a confirmation of the notion of China as a system of 'socialism with Chinese characteristics'. Having set the legal (and conceptual) norms, confirming and reiterating the CPC's mandate of representing the highest authority, the document goes on with a few principles on equality before the law, the dominant position of the People, and a necessary rootedness of socialism with Chinese characteristics in the 'Chinese reality' (Article1), before continuing with more concrete reforms in the juridical system.

Interestingly, the Decision also demands that newly elected and appointed People's Congress officials at all levels pledge allegiance to the Constitution of China. This oath is not demanded from Party cadres, according to the Decision, since they already swear an oath to the Party's own constitution. Moreover, the 4th of December is designated as 'Constitution Day', promoting general education and awareness of the constitution as the 'basic law' (Article 2, Section 1). The work style of officials is to be changed into one of 'ruling according to law' and 'ruling according to virtue' (Article 1). The introduction of virtue into the legal framework may seem odd, yet it corresponds with the goal of establishing a specifically Chinese system, building on Chinese morals and values, emphasizing education and cultivation. These aspects are strongly promoted in other political initiatives, such as the 'Chinese Dream', the strong anti-corruption efforts, and many other reform packages following the third plenum last year. Supported by a strong propaganda apparatus under Liu Yunshan, this attempt to reform not only institutions, but also the minds of officials and cadres through education campaigns (such as the mass line), appears to be an important part of the reform push under the $\mathrm{Xi}$ administration. 


\section{Legal System Reforms}

While the establishment of the socialist rule of law with Chinese characteristics is a central part of the document, important and more concrete reforms are also mentioned. The Decision clearly acknowledges a broad number of problems in the juridical system, including corruption, poor or selective law enforcement, procedural roadblocks, turf battles among constituencies and departmentalization (Article 1).

Corruption, abuse of office and administrative authority, and violation of procedures in handling such cases, are mentioned several times. Clarification of duties, a system of governmental authority lists, and a general consolidation of authorities (e.g. a reduction of types of law enforcement teams at the lower levels) aim at a more coherent, transparent system. Interference by all Party or state authorities, including leading cadres, in juridical activities is prohibited (Article 4, Section 1 ), and the supervision of higher-level bodies over such activity is to be strengthened (Article 3, Section 5). This is an important statement, since local protectionism, and the authority local governments have over judges, have led to many problems in the past. What is missing though, are concrete institutional mechanisms actually ensuring that these reforms will be followed through, and the language used is one of 'perfecting systems', 'persist in principles', 'strengthen restraints and deepen reforms'. This does not mean they are toothless, but they follow a common pattern in the type of strategic policy documents that rarely spell out in detail exactly what has to be done at local levels, focusing on the ends rather than the means.

Another important announcement is the establishment of circuit courts under the Supreme Court, which are to be held where multiple jurisdictions (e.g. provinces) are involved in cases (Article 4, Section 2 ). This is an important reform, since cross-administrative cases have been very difficult to handle in the Chinese system, where fragmented authorities often hamper the resolution of disputes and questions of jurisdiction and accountability.

Changes have also been announced in the case filing system, likely making it harder for courts (and governments/officials) to reject cases. Especially cases filed concerning abuse of power and corruption are often suppressed, and the Decision introduces a 'case registration system', which possibly makes it harder for courts to not register cases (Article 4, Section 2). It is not clarified how this system will work specifically, but if implemented together with calls for more transparency and openness 
(Article 4, Section 4), it could introduce important mechanisms for better public access to legal protection against abuses of power.

Finally, grass-roots governance systems are to be reformed, including the establishment of a 'community correction law', and the strengthening of grass-roots Party groups (Article 2, Section 4). Moreover, the Decision calls for increased legal education and 'legal popularization' ( $p u f a$ ) (Article 5, Section 1), increased 'consciousness of rule of law governance' among grass-roots cadres, as well as legal education of the population in general, through tertiary education, textbooks and legal research (Article 6, Section 3).

\section{Another Round of 'Soft Centralization'?}

A generally observable trend under Xi Jinping, has been a 'soft centralization' of authority, now including a number of important mechanisms in the legal system. Prime examples are the career management of judges, which is moved to the provincial level, but also the increased auditing and supervision authority handed to department/provincial level Party and state organs. Capacities of the 'central government's macro-level management' are to be increased, and the top-down supervision of higher-level bodies over lower-level bodies is reconfirmed as an important principle (Article 3, Section 1). An especially important reform is the centralization of auditing and personnel issues at the provincial level, such as the selection of judges and prosecutors. Their appointment will now be overseen by provincial-level courts, which are to establish a selection system based on their performance at lower levels (Article 6 , Section 1). This is important, since judges and prosecutors now will have to work their way up through the system, being reviewed by courts on higher levels and largely beyond the control of the government of the level they work at. This is supported by another point, stating that judges can only be removed or suspended based on unlawful action (as opposed to the sole decision by powerful individuals or government organs) (Article 4, Section 1).

These reforms are meant to give courts more independence, especially from local governments' interference, as well as creating a more performance-based career path for judges, more aligned to the civil service system. What is not mentioned, however, is the potential discretionary power of the CPC in the appointment of judges, or in all other matters if seen necessary. This will not change; in fact, it may be strengthened, since the general role of the Party as the legal guardian 
of the Constitution and the watchman of the juridical process has been clearly confirmed as well. Checks and balances are the normative values richly added to the Decision, demanding cadres and authorities always act responsibly and abide by the law, rule according to 'virtue' (Article 1), establish a 'rule of law consciousness' throughout society (Article 5, Section 1) and only interfere when it is required to prevent unlawful action within the system.

\section{Drafting the Decision}

Drafting major Chinese documents is a protracted process. According to Xi Jinping's own lengthy explanation of the background and content of the Decision, work on the document started in January of this year when the Politburo decided that the focus of the Fourth Plenum would be discussing how to 'move the country according to the law forward' (Xinhua 2014b). A drafting group was formed with Xi as head and NPC chairman Zhang Dejiang and Central Discipline Inspection Commission (CDIC) chairman Wang Qishan as deputy heads. In addition, about 70 leading officials from relevant departments including 'provincial leading comrades' participated. On 27 January, the Party centre issued a notice soliciting opinions on questions pertaining to the theme of the upcoming plenum. On 12 February, the drafting group held its first meeting. During the following eight months the standing committee convened three meetings and the full Politburo two meetings to discuss the drafting process. Xi Jinping disclosed that the drafting group also had solicited the opinions of old Party leaders (Xinhua 2014b). Thus, although the drafting process is controlled by $\mathrm{Xi}$ Jinping, he is careful to aim for a consensus among current and former Party leaders.

\section{Corruption Campaign}

The promulgation of the Decision is not only part of the reform process resumed at the third plenary session in 2012, it should also be seen in the context of the ongoing anti-corruption campaign. This campaign started immediately after Xi Jinping took over in November 2012. It has now been going on for two years and there are no signs that it will end any time soon. On the contrary, Wang Qishan, the head of the Central Disciplinary Committee, has said that the campaign will last for a long time. So far, the result has been the investigation of thousands of officials, many of whom have been expelled from the Party for corruption and 
subsequently handed over to the official courts for further prosecution. The campaign has not only targeted lower-level officials, but also an unprecedented number of officials at the vice-ministerial-level and above. In fact, more than 30 of these 'tigers' have been investigated and detained (Chen 2014). Among them are state-level leaders such as former member of the standing committee of the Politburo, Zhong Yongkang, and former vice-chairman of the Central Military Commission, Xu Caihou.

While member of the standing committee of the Politburo, Zhou Yongkang was head of the political-legal commission and thereby in charge of domestic security and maintenance of order. This included the police force, the courts and the procuratorate. Apparently, unprecedented spending induced rampant corruption and malfeasance in the legal and security departments. Li Dongsheng, vice-minister of Public Security and Liang Ke, director of the Beijing Municipal Bureau of State Security, are examples of high-level officials who have been taken into custody for corruption. The police, state security, armed civil militia, courts and jails have now been placed under the command of the newly established National Security Commission headed by Xi Jinping. It is clear that the Party has felt a need to follow up on these administrative measures by calling for a strengthening of the legal basis and framework.

Associated with the anti-corruption campaign is an extra-extravagance campaign, which has also been ongoing since the end of 2012. In December 2012, Xi Jinping announced the so-called Eight Directives (baxiang guiding) to curb red tape and extravagance, and in December 2013, the Party circulated the so-called Six Injunctions (liuxiang jinling) to limit receptions, travelling, banquets and all forms of gift giving. The Decision reiterates these limits on public spending by officials in order to put an end to the pervasive abuse of power and the distortion of rules for personal gain and for the benefit of friends and family.

\section{Conclusion}

The amount of text in the Decision spent on the clarification and formulation of the establishment of the socialist rule of law system, and the CPC's role as the leading authority in the process, indicates how important the reform of the Party and the legal system is for the current leadership. It is also a reflection of the consistent logic of the reform programme under $\mathrm{Xi}$, where institutional development and reform are driven and defined by the central role of the CPC. The development and strengthening of socialism with Chinese characteristics as a distinctively 
Chinese system seems to be the key goal of the Decision. In this sense, the document forms an important addition to the conceptual foundation for the CPC and its leadership of the Party-state. Thus, it supplements the policy goals formulated at the third plenary session last year. More policy documents covering other areas of the economic-political-social system can be expected as the new leadership with Xi Jinping in the driver's seat consolidates its power.

Kjeld Erik Brødsgaard is Professor and Director, Asia Research Centre, Copenhagen Business School. Email: keb.int@cbs.dk

Nis Grünberg is a PhD fellow, Asia Research Centre, Copenhagen Business School, and the Sino-Danish University Centre for Research and Education, Beijing. Email:ng.int@cbs.dk

\section{REFERENCES}

Brødsgaard, Kjeld Erik, and Nis Grünberg 2014. 'Key Points of China's Economic Programme after the Third Plenum of the CPC'. China Report 50 (4): 1-17.

Chen, Gang 2014. 'The "Tigers" in Xi Jinping's Anti-Corruption Campaign'. EAI Background Brief 933 (30 June).

Clarke, Don 2014. 'The Fourth Plenum's Decision: My Take', 29 October. Available at: lawprofessors.typepad,com/china_law_porf_blot/2014/10/the-fourth-plenumdecision-my-take.html (accessed 14 November 2014).

Huang, Cary 2014. 'Rule of law: one term, two characters, many meanings'. South China Morning Post, 10 November. Available at: http://www.scmp.com/news/china/ article/1635985/rule-law-one-term-two-characters-many-meanings (accessed 10 November 2014).

Minzer, Carl 2014. 'What Does China Mean by "Rule of Law"?' Foreign Policy, 20 October. Available at: http://www.foreignpolicy.com/articles/2014/10/20/what_does_china_mean_by_rule_of_law (accessed 10 November 2014).

Xinhua 2013. 'zhonggong zhongyang guanyu quanmian shenhua gaige ruogan zhongda wenti de jueding' (CPC Central Committee Decision on Several Major Issues of Deepening Reform). Available at: http:/ / news.xinhuanet.com/politics/2013-11/15/ c_118164235.htm (accessed 10 November 2014)

Xinhua 2014a. 'zhonggong zhongyang guanyu quanmian tuijin yi fa zhi guo ruogan zhongda wenti de jueding' Decision of the CPC Central Committee Concerning Some Major Questions in Comprehensively Moving Governing the Country According to the Law Forward). Available at: http:/ / news.xinhuanet.com/politics/2014-10/28/ c_1113015330.htm (accessed 10 November 2014).

Xinhua 2014b. 'Xi Jinping: guanyu 'zhonggong zhongyang guanyu quanmian tuijin yi fa zhi guo ruogan zhongda wenti de jueding' de shuoming' (Xi Jinping: Explanation regarding the Decision of the CPC Central Committee Concerning Some Major Questions in Comprehensively Moving Governing the Country According to the Law Forward). Available at: http://news.xinhuanet.com/politics/2014-10/28/ c_1113015372.htm (accessed 10 November 2014). 